\title{
Assessing the Factors Influencing Service Innovation Capabilities and Performance
}

\author{
Nor Asiah Omar ${ }^{1 *}$, MuhamadAzrin Nazri², Syed Shah Alam¹, Azhar Ahmad ${ }^{1}$ \\ ${ }^{1}$ Universiti Kebangsaan Malaysia, Selangor, Malaysia \\ 2Islamic Science University of Malaysia (USIM), Malaysia \\ norasiah@ukm.edu.my, shahalam@ukm.edu.my, azah@ukm.edu.my, muhdazrin@usim.edu.my
}

\begin{abstract}
Innovation has been recognized as a central source of business growth and a key determinant of competitive advantage for many organizations. This paper seeks to address two main objectives. The first objective is to examine the direct effect of organizational structure (i.e. centralization and formalization), transformational leadership, organizational learning and customer orientation on innovation capabilities. The second objective is to examine the effect of innovation capability and organizational performance. Findings show that customer orientation, organizational learning, and transformation leadership had significant positive effects on innovation capability. The results further show that innovation capability had a significant impact on organizational performance.
\end{abstract}

Keywords: Innovation, performance, organizational learning, transformational leadership, organizational structure, customer-oriented

\section{Introduction}

Studies on the current business landscape indicate that services are becoming a major focus. Most developing countries, which historically have concentrated on manufacturing, are now experiencing fast service growth (Boswijk et al., 2007). Similar trends are developing in other countries as well; for instance, in Malaysia the service sector plays a primary role in economic growth. This sector is estimated to expand at $6.3 \%$ per annum, contributing 53\% to GDP. During the Tenth Malaysia Plan (RMKe-10), the service sector growth was supported largely by the wholesale and retail trade, finance and insurance, and communications sectors. Investment in the service sector increased by $9.5 \%$ annually to RM125.3 billion in 2013, as a result of expansion in domestic investment (Economic Planning Unit, 2015). In the Malaysia-OECD Roundtable Discussion on Technology, Innovation and Industry 2013, innovation was acknowledged as an important driver of value creation, economic growth, and social welfare (Hutschenreiter, 2013). The service sector has played an important role in economic growth in Asia in recent years and has been identified as the engine to trigger an economic rebound (Wilson, 2014).

A growing body of literature suggests that a competitive advantage can be enhanced through services (Prahalad \& Ramaswamy, 2004). Indeed, several researchers have introduced the term "experience economy," which emphasizes services that must "orchestrate memorable events for their customers, which in turn will create value to firm" (Pine \& Gilmore, 1999). As service economy is growing and customers are demanding better value and improved service, the innovation process is becoming essential in order to provide a timely response to the market with new or improved service solutions (Hidalgo \& D'Alvano, 2014). Recently, researchers have shown an increased interest in service management, particularly service innovation (Storey et al., 2016; Witell et al., 2016). The issue of innovation has received considerable attention due to the complexity and intangible nature of services (Lusch \& Nambisan, 2015). However, in Malaysia innovation in the service sector has not received vast attention despite its significant contribution to the economic growth and employment of the country (Narayanan and Hosseini, 2014). According to compared with studies on the manufacturing sector in Malaysia, there is a dearth of researchers on innovation in services. Moreover most of the studies on innovation are likely to focus on large firms as innovation is seen as the least vital for SMEs. Recent report by Malaysia Economic Planning Unit (EPU) (2015) indicated, several important issues relate to the service sector which includes insufficient skilled human capital, low capabilities, and low technology adoption. 
From the strategic point of view, service organizations are required to innovate in order to experience sustained growth, raise the quality and productivity levels of services, respond to changing customer needs and expectations, or stand up to superior competitive service offerings (Magnusson et al., 2003). Although the role of innovation is vital for organizations as a key strategy for growth and sustainability in the service sectors, several researchers have emphasized the intangible aspects, resulting from the interactive nature of service, that create the peculiar way in which service innovates (Miles, 2000). Innovation in service delivery has forced retail operators to rethink their strategies in treating customers and meeting their expectations. A study in Malaysia's SME retail business found that, among other problems faced by these retail outlets, to introduce new innovation in service delivery they encounter inadequate knowledge and skill in retailing, difficulty in getting competent employees for stores, and lack of skills in managing marketing activities (Hamid, Baharun \& Hashim, 2006).

According to Gallouj (2002), service innovation requires greater consideration of the organizational aspects, beyond the traditional product and process innovation method through the diffusion of knowledge and skills rather than through the purchase of machinery or technology. The innovative capability varies by firms and it is determined by a vast and complex number of aspects, both internal and external to the firm (Silva, 2007). Scholars such as Shih et al. (2014) focus on study innovation from service-oriented setting, while Ngo and 0 'cass (2012) call for research in non-technical context to investigate how service-based retailers implement innovations in service delivery and processes (Ponnam \& Balaji, 2015). Although several studies on innovation were conducted in service context, researchers have noted that studies involving innovation in service industries are still lacking about the conditions for and consequences of innovation which need further attention (Hristov \& Reynolds, 2015; Djellal et al., 2013; Kimberly \& Evanisko, 1981; Tidd, 2001). Several researchers have identified contextual, structural and organizational factors that differentiate innovative from non-innovative firms (Bayo-Moriones \& Lera-Lopez, 2007; Slappendel, 1996) while others focused on the organizational supports for developing absorptive capacity and technology innovation (Ahmed Aljanabi et al., 2014).

Hence, the insufficient researchers that have established the relationships that may exist between the variables of current study create the theoretical gaps within the current context of the study. Referring to the above-mentioned gaps, based on the contingency theory (Drejer, 2002; Tidd, 2001) and the resource-based view (RBV) (Barney, 1991) this study aims to examine the influence of organization structure (centralization and formalization), organization learning, transformational leadership and customer centered on service innovation capabilities. This work aims to close the literature gap on the determinants of service innovation capabilities and its impact on organizational performance. Consequently, the aim of this study is to investigate the organizational factors in explaining innovation capabilities and business performance of the service sector in Malaysia. It is expected that the study will assist the academicians, administrators, and government policy makers to gain a better understanding of the pivotal factors affecting innovation capabilities and performance of firm's particularly involving service sector. Innovation capabilities involving service sector is new; therefore, it is expected that this research will stimulate further research to add to the extant body of knowledge in the sustainability of service sector.

\section{Literature Review}

Organizational structure: Businesses require a well-designed organizational structure to grow and be profitable (Tran \& Tian, 2013). Several researchers noted that organizational structure decrease ambiguity helps explain and predict behavior (Sablynski, 2010) and manage resources (Brown, 1995). Organization structure can be defined as the architecture of business competence, leadership, talent, functional relationships and arrangement (Russell \& Russell, 1992). Kartz and Kahn (1978) describe organizational structure as the relatively enduring allocation of work roles and administrative mechanisms that create a pattern of interrelated work activities and allow the organization to conduct, coordinate and control its activities. Among the most important components of the organizational structure are formalization and centralization (Zheng, Yang \& Mclean, 2010). Formalization has been defined as "the degree to which rules define roles, authority relations, communications, norms, sanctions, and procedures" (Jaworski \& Kohli, 1993, 
p.54). While centralization refers to the "inverse of the amount of delegation of decision-making authority throughout an organization and the extent of participation by organizational members in decision-making" (Jaworski \& Kohli, 1993). Centralization can be beneficial in predictable, less turbulent environments where market demand is stable and simple (Ruekert et al., 1985). Previous researchers have suggested that, one of the most important factors facilitating and reinforcing the innovation ability in an organization is a convenient structure and a suitable formation designed to fulfill the ultimate goal (Carmona-Lavado, 2010). Wan et al. (2005) indicated a positive and significant relationship between innovation level and structural decentralization, and the tendency to take risks and to change ideas. Accordingly, this study hypothesis:

H1a: There is a relationship between centralization and service innovation capabilities. $H 1 b$ : There is a relationship between formalization and service innovation capabilities.

Organization learning: Learning capability is considered as one of the essential elements for the organization that can be conducive to the growth and innovation. Organizational learning can be regarded as a dynamic process including the knowledge creation, acquisition, and collection with the aim to the development of resources, and capacity that leads to the better performance of the organization (Perez et al., 2005).Therefore, the spread of learning culture among an organization's member's leads to the production and innovation of knowledge systems and new creative ideas in the organization that finally generates the innovation (Samadsaki et al., 2013). Several researchers have identified that the market-oriented learning (OL) and self-learning are among the important factors that influence organizational innovation (Hung, et al., 2010; Jiménez \& Valle, 2011). An organization that invests in learning is likely to possess the state-of-the-art technology to create greater products and processes innovation (Calantone et al., 2002; Damanpour, 1989). Moreover, innovation capability is positively related to firm performance (Calantone et al., 2002; Slater \& Narver, 1994). Thus, it is proposed:

H2: There is a relationship between organizational learning and service innovation capabilities.

Transformational leadership: Leadership is an influencing factor on how innovation occurs in organizations both in terms of ideas and motivation to overcome obstacles. Among the traditional leadership styles, transformational leadership has been suggested as the most promising way of leading innovation effectively (Rosing et al., 2011). Several researchers have found the significant and positive relationship between leadership style and innovation (Garsia-Morales, 2012; Norouzy et al., 2013). Transformational leaders facilitate innovative activities at organizational levels using the employee's mental encouragement and their motivation stimulation (Vaccaro et al., 2012). In view of this, the following hypothesis is suggested: H3: There is a relationship between transformational learning and service innovation capabilities.

Customer orientation: Customer orientation can be defined as the degree to which the business unit obtains and uses information from customers, develops a strategy which will meet customer needs, and implements that strategy by being responsive to customers' needs and wants (Ruekert, 1992). According to Korunka et al. (2007), customer orientation is part of corporate culture and characterizes not only the company's opinions but also its employees' behavior in dealing with customers. The desire to continually adapt to customer needs and wants more than the competitors often produce an organization that have strong customer-focused and need to innovate (Dukicet al., 2015; Santos-Vijande \& Gonzales, 2007). Several past studies asserted that customer orientation has a positive effect on innovation at product, process and organizational level (Jiménez-Zarco et al., 2011). In view of the preceding discussion, the following hypothesis is proposed:

H4: There is a relationship between customer orientation and service innovation capabilities.

Innovation capability and performance: Several researchers suggested that innovation capability as the skills/knowledge and abilities that enable the application of resources, to effectively and continuously transform knowledge and ideas into new product/service to benefit the firm and its stakeholders (Kindström et al., 2013). According to Tamer Cavusgil, Calantone \& Zhao (2003) a firm with high innovation capability employs a learning-by-doing effect, which helps firms to sustain their competitive advantage and prevent competitors from imitating the know-how tacit knowledge. The literature on innovation suggested that innovation is positively related to organization's performance (Calantone et al., 2002; Gunday et al., 2011). Organizational performance is an indicator that measures how effective an organization accomplishes its 
objectives (Valmohammadi, 2012). Past study suggested the performance of organizations entails performance in finance such as profit and sales growth (Kuei et al., 2001) and non-financial measures such as satisfaction (Venkatraman \& Ramanujan, 1986). Discussion in past studies showed no consensus on the appropriate measures of firm performance (Ambad, 2014). Some researchers used a balance approached of adopting both financial and nonfinancial measures to assess organizational performance (Sneyd \& Rowley, 2004; Wang et al., 2012). Another aspect of measuring performance in previous studies used the two approaches methods: objective (actual information) and perceptual (subjective) (Andersen, 2010). Many studies in the area of entrepreneurship are based on the perceptual performance data (Andersen, 2010; Wiklund \& Shepherd, 2005). Hence, perceptual (subjective) measures of performance would be employed in this study. With regards to the relationship between innovation and performance, many scholars have found that innovation influence organization performance (Calantone, Cavusgil, \& Zhao, 2002; Saunila et al., 2014). Damanpour et al. (1989) attempted to investigate the relationship between administrative and technical innovations and organizational performance. They posited that organizations that have a high rate of adoption of both administrative and technical innovations would have higher performance level than those that have a low rate of adoption of both administrative and technical innovations. In this paper based on the above discussions, we propose the last hypothesis:

\section{H5: There is a relationship between service innovation capabilities and organization performance.}

Research Model: A comprehensive literature review shows a lack of empirical studies that examine the impact of organizational culture, structure, leadership styles, learning, and customer-centered on innovation capability and the effect of innovation capability on performance in the context of service. Hence, a conceptual model was proposed as shown in Figure 1. In this model, the organizational structure was operationalized with two dimensions: formalization and centralization. All the four factors (organization structure, learning, transformational leadership and customer orientation) are related to service innovation capabilities (H1a$\mathrm{H} 4)$ which then impact organization performance (H5).

\section{Methodology}

Figure 1: Research model on factors affecting innovation and performance

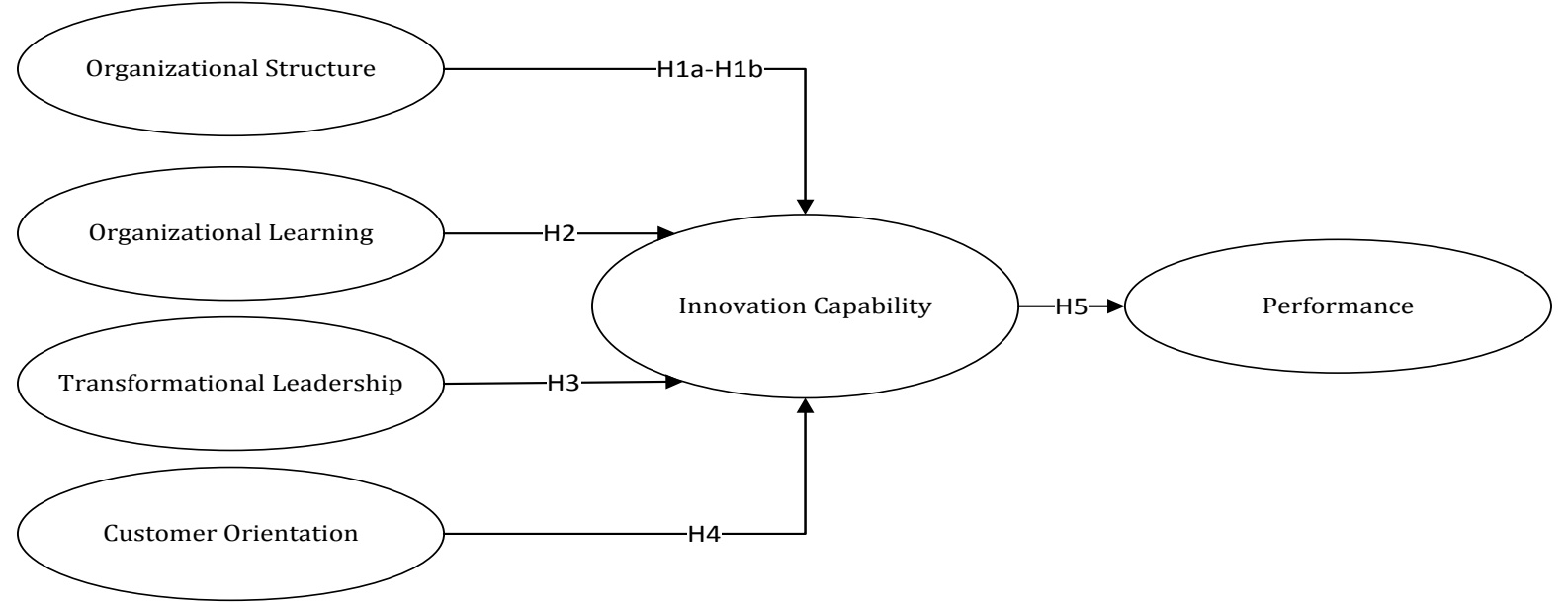

Sample and data collection: In order to understand the nature of innovation service, the data of this study was collected in September to November 2015 by sending a questionnaire to the managers of 20 firms in five service sectors: food, travel agency, communication, insurance, and education services located in Klang Valley, Malaysia. Klang Valley is where the capital of Malaysia is situated. It was reported that most of the modern establishments in Malaysia are located in the Klang Valley (Euromonitor, 2001). Managers are chosen as respondents because they are involved in the management of organizational affairs and processes. To uphold confidentiality, the name of this organization is kept anonymous. This study used purposive sampling and the data were collected by using self-administered questionnaires distributed via the drop and 
collect technique. Drop and collect technique involves researchers and/or trained field assistants deliver the questionnaire directly to the target respondents or through gatekeepers and collect back the completed questionnaire (Ibeh et al., 2004). To ensure that the respondents were staff that holds a position as a manager or above with more than five years working experience and well versed in the nature of service work practice in their organizations, the questionnaires were handed over to the representatives who were also employees of the company for data collection. The questionnaires were delivered and collected by the researcher. The survey questionnaires method was used to further comprehend the staff characteristics, and the nature of work, as well as the working environment in the service organizations. The gathered information is then used for the actual research. Of the 250 questionnaires that were distributed, 209 participants completed the questionnaires, representing a response rate of 84 percent. The survey questionnaires were answered by participants by their consent and a voluntary basis.

Multiples item scales were used to measure each construct in this study. The questions in the questionnaire are designed based on a review of the literature. All the five factors namely organizational structure, transformational leadership, customer orientation and learning capabilities were adopted from Hoonsopon and Ruenrom (2012); Sivadas and Dwyer (2000); Olson et al. (2005); Podsakoff et al. (1996); Nasution et al. (2011) and Jerez-Gómez et al. (2005). While innovation capabilities and organizational performance were measured using a multi-item scale developed by Hogan et al. (2011); and Luca and Atuahene-Gima (2007) respectively. All items in this study were measured on a 5-point Likert scales ranging from "strongly disagree" (1) to "strongly agree" (5). Of the 209 valid responses, $46 \%$ came from insurance sectors, $20 \%$ and $18 \%$ from food and communication sectors respectively. Majority of respondents were female respondents (53 per cent). In terms of income, 36 per cent of the respondents had an income of between MYR6,000 to MYR7,999. The highest age group distribution of the respondents falls in the 36 to 45 years old age group (40 per cent), followed by 33 per cent in the 26-35 years old age group. Regarding ethnicity, 44 per cent of the respondents are Malay, 24 per cent are Chinese and 18 per cent are Indian. The majorities (65 per cent) of the respondents are married with children while 25 per cent are single. A total of 81 respondents (39 per cent) are degree holders, 39 respondents ( 19 per cent) are postgraduate holders, and 41 respondents ( 20 per cent) are diploma holders. In terms of the size of the company, 54 per cent of the respondents were from an organization with more than 300 employees; 16 per cent from 201-200 employees; and 13 per cent from 61100 employees.

\section{Findings}

The internal reliability of the items was verified by performing the Cronbach's alpha analysis. According to Sekaran and Bougie (2016) an alpha value of less than 0.6 is seen as a weak reliability while an alpha value of more than 0.7 is regarded as strongly reliable. The Cronbach's alpha for organizational learning was 0.89 , transformational leadership was 0.90 , centralization was 0.86 , formalization was 0.85 , customer-centered was 0.92 , innovation capabilities was 0.95 and organizational performance was 0.95 . Reliability statistics for all the factors passed the cut-off value of 0.70 (Nunnally, 1978). The impact of multicollinearity is a concern for interpreting the regression variance (Hair et al., 2009). Highly collinear variables can distort the results substantially and thus not generalizable. The variance inflation factor VIF output for each construct was lower than the common cut-off threshold of 5 . Hence, collinearity among the predictor constructs was not an issue. 
Table 1: Multiple regression analysis

\begin{tabular}{|c|c|c|c|c|}
\hline Factors/determinants & $\begin{array}{l}\text { Standardized } \\
\text { Coefficients }\end{array}$ & Beta & $\mathbf{t}$ & Sig. \\
\hline (Constant) & & & 2.025 & .044 \\
\hline Centralization & .045 & & 0.838 & .403 \\
\hline Formalization & .052 & & 0.863 & .389 \\
\hline Organizational Learning & .212 & & 2.691 & .008 \\
\hline Transformational Leadership & .206 & & 2.455 & .015 \\
\hline Customer Orientation & .437 & & 6.062 & .000 \\
\hline \multicolumn{5}{|c|}{$F(5,200)=55.26, R^{2}=0.656$, Adj. $R^{2}=0.644$} \\
\hline Dependent Variable: Service In & n Capabilities & & & \\
\hline
\end{tabular}

Table 1 presents results of a multiple regression analysis used to evaluate the strength of the proposed relationship. Seven hypotheses were formulated and all the variables were retained after performing the reliability and validity testing. Multiple regression prediction models follow the guidelines by Hair et al. (2009) to test the impact of formalization, centralization, transformational leadership, customer orientation and learning capabilities with service innovation capabilities as the dependent variable. The generic model, without controlling for organizational and individual factors, is significant at $1 \%$ level ( $\mathrm{F}$ value $=55.26$ ). Table 1 shows the multiple regression results obtained revealed that out of six hypotheses (H1a-H5), four hypotheses were found to be significant. According to the regression results, organizational learning, transformational leadership, customer orientation, and organizational structure (centralization, and formalization) jointly explained $64 \%$ of the total variance in innovation. Four factors had significant positive relationship with innovation: organizational learning $(\beta=.212 ; p<0.01)$, transformational leadership $(\beta=.206$; $\mathrm{p}<0.01$ ), and customer orientation $(\beta=.437 ; \mathrm{p}<0.01$ ). These results provide support for $\mathrm{H} 2$ (a significant positive relationship between organizational learning and innovation), H3 (a significant relationship between transformational leadership and innovation), and $\mathrm{H} 4$ (a significant positive relationship between customer orientation and innovation) but not for H1a (relationship between centralization and innovation), and H1b (relationship between formalization and innovation). Customer orientation displays the largest coefficient on innovation compared to other factors. With regards to the effect of innovation on performance, the multiple regression results in Table 2 showed that service innovation capabilities was found to be significantly and positively related to organizational performance $(\beta=.804 ; \mathrm{p}<0.01)$, thus H5 was supported.

Table 2: Multiple regression analysis

\begin{tabular}{|c|c|c|c|c|}
\hline Factors/determinants & $\begin{array}{l}\text { Standardized } \\
\text { Coefficients }\end{array}$ & Beta & $\mathbf{t}$ & Sig. \\
\hline (Constant) & & & 5.013 & .000 \\
\hline Service innovation capabilities & .804 & & 19.45 & .000 \\
\hline \multicolumn{5}{|c|}{$F(1,207)=378.40, R^{2}=0.646$ Adj. $R^{2}=0.645$} \\
\hline Dependent Variable: Organizati & erformance & & & \\
\hline
\end{tabular}

Discussion and Implication: The objectives of this study were to investigate the influence of organizational learning, transformational leadership, customer orientation, and organizational structure on innovation capabilities. Additionally, this study proposed the relationship between innovation and organization performance. Six hypotheses were tested, four of which were supported. The findings show customer orientation was the most significant antecedents to innovation capabilities followed by organizational learning and transformational leadership. The significant relationship between customer orientation and innovation was in line with past literature (Jiménez-Zarco et al., 2011) indicating a possible association. Therefore, businesses that understand and anticipate customers' latent and future needs allow firms to be more innovative and pursue market opportunities that are not evident to competitors (Tellis et al., 2009). It is further found that most innovative companies, instead of competing on accepted performance dimensions, differentiated themselves by adapting to environmental changes and exploiting emerging or unarticulated customer needs (Berman \& Hagan, 2008; Day, 2011). 
Further, there was significant a relationship between organizational learning, and innovation, which are consistent with the findings of previous studies such as Atuahene-Gima, 2005; Westwood \&Low, 2003; Weerawardena, 2006). This implies that one of the key aspects of an innovative firm is the strength of its organizational culture towards learning orientation. According to Sinkula et al. (1997, p.309), a learning orientation influences "the propensity of the firm to create and use knowledge". Hence, service organizations need to spread the shared principles, ideas and belief on innovation through learning culture among an organization's member's as it shapes the patterns dealing with novelty, individual initiatives and collective actions in regard to risks as well as opportunities (Kaasa \& Vadi, 2008; Samadsaki et al., 2013). According to the results for effects of transformational leadership on innovation is likely to show a positive and significant relationship. In this regard, this study confirmed the results of Gumusluoğlu and Ilsev (2009), which exhibits that transformational leaders not only promote innovative activities within the organization but also ensure their market success. Several past studies have suggested the important task of the leader to set an appropriate tone and driver for innovation (Yadav, Prabhu \& Chandy, 2007) which transformational leadership seems to be more appropriate for stimulation creativity and innovation (Jamaludinet al., 2011; Rosing et al., 2011.

In addition, the results provide no support for the effect of organizational structure (formalization, and centralization) on the relationship of innovation. The results are inconsistent with Carmona-Lavado et al. (2010) and John and Doty (1996), which highlighted the importance of convenient structure and a suitable formation designed to achieve innovation. However, the results are in line with a study conducted by Lai et al. (2014). As mentioned by Fredrickson (1986) and Chandler (1962) organization structure follows strategy and strategy follow environment in a high degree division between the roles and function the dynamic capability to change accordingly will be more complex to the environment. Another possible reason is innovations are typically complex procedures, consisting of a variety of different activities depending on the stages or phases, like the ideation and implementation stage (Amabile et al., 1996; Anderson et al., 2004) or the distinction between conceptualization, development, and commercialization (Stemberg, Kaufman \& Pretz, 2004). These distinctions are relevant because there are strong indications that different phases of innovation activities require different demands of strategies to boost innovation (Anderson et al., 2004; Gilley et al., 2008). Finally, innovation capabilities have a strong positive relationship with firm performance, as organization enhances its capacity to adjust to market demands through innovation, this allows the firm to sustain their advantages through improvement in organization performance. The finding is in accordance with various empirical studies supporting this relationship (Cho \& Pucik, 2005; Javier Llorens Montes et al., 2005).

The results have important implications for service managers. This is particularly vital to Malaysia service sector because according to the recent report (Economic Planning Unit 2015), the service sector in Malaysia continue to be the primary propeller to the economic growth for the country. This sector is estimated to expand at $6.3 \%$ per annum, contributing 53\% to GDP. Moreover, the investment in the services sector increased by $9.5 \%$ annually to RM125.3 billion in 2013, as a result of expansion in domestic investment (Economic Planning Unit 2015). Innovation in service delivery has forced many operators to rethink their strategies in treating customers and meeting their expectations.

This study finding are also useful for managers of service firms as well as policy-makers regarding the dependence of performance on innovation capability and the effective implementation of organization structure, leadership, organization learning and customer orientation. In this respect, the study results allow managers to understand the important factors that contribute towards a successful innovative firm. First, the findings of this study provide evidence that customer orientation significantly influences innovation capabilities, managers need to focus on enhancing customer value through customer focus to increase the level of innovation. Secondly, the current study results will also be helpful in promoting culture that assists organizational learning to enable a firm to achieve success in innovation. Both learning and innovation are important factors that allow response to changes in the environment and basis for long-term survival, competitiveness and achieving greater performance. Therefore, it is important to point out that managers should encourage employees to use company time to acquire knowledge that may lie outside the immediate 
scope of their work. Lastly, the findings of the study can be used to prioritize the practice of innovation to be utilized by mangers to boost the organization performance. The results can help to design strategies to pursue creativity and innovation, which can lead to higher performance.

Limitations and Future Research: There are some limitations that suggest caution in assessing the findings. First, the factors used in this study are confined to several organizational factors (organizational structure, organizational learning, transformational leadership and customer orientation)which do not cover all the factors that can contribute toward innovation capability in service firms. The method used for this research can be a limitation as well because purposive sampling technique was used in collecting the data. Thus the results of the study cannot be generalized to represent the whole population. Moreover, this study focuses on Malaysian service firms located at Klang Valley thus; the result may not sufficiently represent all service firms in Malaysia. In order to enhance the generalisability of the results, future study should cover other countries, type, and size of firms and organizational age. Finally, future research should as well consider other moderating and mediating variables in the context innovation and performance.

Acknowledgments: Fundamental of Research Grant Scheme: FRGS/1/2013/SS05/UKM/02/10.

\section{References}

Ahmed Aljanabi, A. Q. R., Mohd Noor, N. A. \& Dileep, K. M. (2014).The mediating role of absorptive capacity in its effect on organizational support factors and technological innovation. Information Management and Business Review, 6(1), 25-41.

Amabile, T. M., Conti, R., Coon, H., Lazenby, J. \& Herron, M. (1996).Assessing the work environment for creativity. Academy of Management Journal, 39(5), 1154-1184.

Ambad, S, N. A. (2014). Corporate entrepreneurship as a determinant of large firm performance: Evidence from Malaysia (PhD Thesis). Science Islamic University of Malaysia.

Atuahene-Gima, K., Slater, S. F. \& Olson, E. (2005). The contingent value of responsive and proactive market orientations for product innovation. Journal of Product Innovation Management, 22(6), 464-82.

Anderson, N., De Dreu, C. K. \& Nijstad, B. A. (2004). The routinization of innovation research: A constructively critical review of the state-of-the-science. Journal of Organizational Behavior, 25(2), 147-173.

Andersen, J. (2010). A critical examination of the EO-performance relationship. International Journal of Entrepreneurial Behavior and Research, 18(1), 98-122.

Barney, J. (1991). Firm resources and sustained competitive advantage. Journal of Management, 17(1), 99120.

Bayo-Moriones, A. \& Lera-López, F. (2007).A firm-level analysis of determinants of ICT adoption in Spain. Technovation, 27(6), 352-366.

Berman, S. \& Hagan, J. (2008). How technology-driven business strategy can spur innovation and growth. Strategy and Leadership, 34(2), 28-34.

Boswijk, A., Thijssen, T. \& Peelen, E. (2007). The Experience Economy: A New Perspective. Pearson Education.

Brown, J. J. (1995). Flattening the Organizational Hierarchy of the Fairfax County, Virginia Fire and Rescue Department. National Fire Academy.

Calantone, R. J., Cavusgil, S. T. \& Zhao, Y. (2002).Learning orientation, firm innovation capability, and firm performance. Industrial Marketing Management, 31(6), 515-524.

Carmona-Lavado, A., Cuevas-Rodríguez, G. \& Cabello-Medina, C. (2010). Social and organizational capital: Building the context for innovation. Industrial Marketing Management, 39(4), 681-690.

Chandler, A. (1962). Strategy and Structure: Chapters in the History of the Industrial Enterprise, Cambridge/Mass.

Cho, H. J. \& Pucik, V. (2005). Relationship between innovativeness, quality, growth, profitability, and market value. Strategic Management Journal, 26(6), 555-575.

Damanpour, F., Szabat, K. A. \& Evan, W. M. (1989).The relationship between types of innovation and organizational performance. Journal of Management Studies, 26(6), 587-602.

Day, G. S. (2011). Closing the marketing capabilities gap. Journal of Marketing, 75 (4), 183-95. 
Denison, D. R. (1996). What is the difference between organizational culture and organizational climate? Academy of Management Review, 21(3), 619-54.

Djellal, F., Gallouj, F. \& Miles, I. (2013). Two decades of research on innovation in services: Which place for public services? Structural Change and Economic Dynamics, 27, 98-117.

Drejer, A. (2002). Situations for innovation management: Towards a contingency model. European Journal of Innovation Management, 5(1), 4-17

Dukic, S., Stankovic, L. \& Lepojevic, V. (2015), Improvement of innovation capacity of SMEs in Republic of Serbia by Connecting with key stakeholders, IInzinerine Ekonomika-Engineering Economics, 26(4), 431-441

Euromonitor International. (2014). Retailing in Malaysia.

Fredrickson, J. W. (1986). The strategic decision process and the organizational structure. Academy of Management Review, 11(2), 280-297.

Gallouj, C. (2002). Innovation in the service economy: The new wealth of nations, Cheltenham: Edward Elagar.

García-Morales, V. J., Jiménez-Barrionuevo, M. M. \& Gutiérrez-Gutiérrez, L. (2012).Transformational leadership influence on organizational performance through organizational learning and innovation. Journal of Business Research, 65(7), 1040-1050

Gilley, A., Dixon, P. \& Gilley, J. W. (2008). Characteristics of leadership effectiveness: Implementing change and driving innovation in organizations. Human Resource Development Quarterly, 19(2), 153-169.

Gunday, G., Ulusoy, G., Kilic, K. \& Alpkan, L. (2011).Effects of innovation types on firm performance. International Journal of Production Economics, 133(2), 662-676.

Gumusluoğlu, L. \& Ilsev, A. (2009). Transformational leadership and organizational innovation: The roles of internal and external support for innovation. Journal of Product Innovation Management, 26(3), 264277.

Hair, J. F., Black, W. C., Babin, B. J. \& Anderson, R. E. (2009). Multivariate Data Analysis 7th ed. Prentice Hall.

Hamid, A. B. A., Baharun, R. \& Hashim, N. H. (2006).Comparative analysis of managerial practices in small medium enterprises in Malaysia. Jurnal Kemanusiaan, 8(2).

Hidalgo, A. \& D'Alvano, L. (2014). Service innovation: Inward and outward related activities and cooperation mode. Journal of Business Research, 67(5), 698-703.

Hogan, S. J., Soutar, G. N., McColl-Kennedy, J. R. \& Sweeney, and J. C. (2011). Reconceptualizing professional service firm innovation capability: Scale development. Industrial Marketing Management, 40(8), 1264-1273.

Hoonsopon, D. \& Ruenrom, G. (2012).The impact of organizational capabilities on the development of radical and incremental product innovation and product innovation performance. Journal of Managerial Issues, 24(3), 250

Hristov, L. \& Reynolds, J. (2015). Perceptions and practices of innovation in retailing: Challenges of definition and measurement. International Journal of Retail and Distribution Management, 43(2), 126-147.

Hung, R. Y. Y., Lien, B. Y. H., Fang, S. C. \& McLean, G. N. (2010).Knowledge as a facilitator for enhancing innovation performance through total quality management. Total Quality Management, 21(4), 425438.

Hutschenreiter, G. (2013). Innovation in Malaysia and the OECD Reviews of Innovation Policy Preliminary Observations, Malaysia-OECD Roundtable Discussion on Technology, Innovation and Industry, Kuala Lumpur. 25 May.

Ibeh, K., Brock, J. K. U. \& Zhou, Y. J. (2004). The drop and collect survey among industrial populations: theory and empirical evidence. Industrial Marketing Management, 33(2), 155-165

Jamaludin, Z., Rahman, N. M. N. A., Makhbul, Z. K. M. \& Idris, F. (2011). Do transactional, transformational and spiritual leadership styles distinct? A conceptual insight. Journal of Global Business and Economics, 2(1), 73-85.

Jaworski, B. J. \& Kohli, A. K. (1993). Market orientation: Antecedents and consequences. Journal of Marketing, 3, 53-70.

Javier Llorens Montes, F., Ruiz Moreno, A. \& Garcia Morales, V. (2005). Influence of support leadership and teamwork cohesion on organizational learning, innovation and performance: An empirical examination. Techovation, 25, 1159-1172. 
Jerez-Gomez, P., Céspedes-Lorente, J. \& Valle-Cabrera, R. (2005). Organizational learning capability: a proposal of measurement. Journal of Business Research, 58(6), 715-725.

Jiménez-Zarco, A. I., Martínez-Ruiz, M. P. \& Izquierdo-Yusta, A. (2011). Key service innovation drivers in the tourism sector: Empirical evidence and managerial implications. Service Business, 5(4), 339-360.

Jiménez, J. D. \& Valle, S. R. (2011).Innovation, organizational learning, and performance. Journal of Business Research, 64(4), 409-417.

John, E. D. \& Doty, D. H. (1996). Modes of theorizing in strategic human resource management: Tests of universalistic, contingency, and configurational performance predictions. Academy of Management Journal, 39(4), 802-835.

Kaasa, A. \& Vadi, M. (2008). How does culture contribute to innovation? Evidence from European countries. Evidence from European Countries (September, 15 2008). The University of Tartu Faculty of Economics and Business Administration Working Paper. (63-2008).

Kartz, D. \& Kahn, R.L. (1978).The Social Psychology of Organizing. 2nd Edition, New York: Wiley.

Kimberly, J. R. \& Evanisko, M. J. (1981). Organizational innovation: The influence of individual, organizational, and contextual factors on hospital adoption of technological and administrative innovations. Academy of Management Journal, 24(4), 689-713.

Kindström, D., Kowalkowski, C. \& Sandberg, E. (2013).Enabling service innovation: a dynamic capabilities approach. Journal of Business Research, 66(8), 1063-1073.

Korunka, C., Scharitzer, D., Carayon, P., Hoonakker, P., Sonnek, A. \& Sainfort, F. (2007). Customer orientation among employees in public administration: A transnational, longitudinal study. Applied Ergonomics, 38(3), 307-315.

Kuei, C. H., Madu, C. N. \& Lin, C. (2001).The relationship between supply chain quality management practices and organizational performance. International Journal of Quality \& Reliability Management, 18(8), 864-872.

Lai, W. H., Lin, C. C. \& Wang, T. C. (2014).Exploring the interoperability of innovation capability and corporate sustainability. Journal of Business Research, 68(4), 867-871

Luca, L. M. D. \& Atuahene-Gima, K. (2007). Market knowledge dimensions and cross-functional collaboration: examining the different routes to product innovation performance. Journal of Marketing, 71(1), 95112.

Lusch, R. F. \& Nambisan, S. (2015). Service innovation: A service-dominant logic perspective. Mis Quarterly, 39(1), 155-175.

Magnusson, P. R., Jonas M. \& Per, K. (2003).Managing user involvement in service innovation experiments with innovating end users. Journal of Service Research, 6(2), 111-124.

Miles, I. (2000) Service innovation: Coming of age in the knowledge-based economy, International Journal of Innovation Management, 4(4), 371-389

Nasution, H. N., Mavondo, F. T., Matanda, M. J. \& Ndubisi, N. O. (2011). Entrepreneurship: Its relationship with market orientation and learning orientation and as antecedents to innovation and customer value. Industrial Marketing Management, 40, 336-345.

Narayanan, S. \& Hosseini, M. P. (2014). Drivers of innovation in the Malaysian service sector: An analysis based on firm-level data. Institutions and Economics, 6(1), 95-118.

Ngo, L. V. \& O'Cass, A. (2012). In search of innovation and customer-related performance superiority: The role of market orientation, Marketing Capability, and Innovation Capability Interactions. Journal of Product Innovation Management, 29(5), 861-877.

Norouzy, A., Dalfard, V. M., Azhdari, B., Nazari-Shirkouhi, S. \& Rezazadeh, A. (2013). Relations between transformational leadership, organizational learning, knowledge management, organizational innovation, and organizational performance: an empirical investigation of manufacturing firms. The International Journal of Advanced Manufacturing Technology, 64(5-8), 1073-1085.

Nunnally, J. C. (1978). Psychometric Theory. 2nd Edition, McGraw Hill, New York, NY.

Olson, E. M., Slater, S. F. \& Hult, T. G. (2005).The performance implications of fit among business strategy, marketing organization structure, and strategic behavior. Journal of Marketing, 69, 49-65.

Pérez López, S., Manuel Montes Peón, J. \& José Vazquez Ordás, C. (2005).Organizational learning as a determining factor in business performance. The Learning Organization, 12(3), 227-245. 
Pine, B. J. \& Gilmore, J. H. (1999). The experience economy: Work is theatre and every business a stage. Harvard Business Press.

Podsakoff, P. M., Mackenzie, S. B. \& Bommer, W. H. (1996). Transformational leader behaviors and substitutes for leadership as determinants of employee satisfaction, commitment, trust and organizational citizenship behaviors. Journal of Management, 22, 259-298.

Ponnam, A. \& Balaji, M. S. (2015). Investigating the effects of product innovation and ingredient branding strategies on brand equity of food products. British Food Journal, 117(2), 523-537.

Prahalad, C. K. \& Ramaswamy, V. (2004).Co-creating unique value with customers. Strategy \& leadership, 32(3), 4-9.

Rosing, K., Frese, M. \& Bausch, A. (2011). Explaining the heterogeneity of the leadership-innovation relationship: Ambidextrous leadership. The Leadership Quarterly, 22(5), 956-974.

Ruekert, R. W., Walker Jr, O. C. \& Roering, K. J. (1985). The organization of marketing activities: a contingency theory of structure and performance. Journal of Marketing, 2, 13-25.

Russell, R. D. \& Russell, C. J. (1992). An examination of the effects of organizational norms, organizational structure, and environmental uncertainty on entrepreneurial strategy. Journal of management, 18(4), 639-656.

Sablynski, C. J. (2012). Foundation of Organizational Structure.

Samad, S., Shakiba, H. \& Savari, M. (2013).Study of the relationship between the organizational learning and organizational innovation at University of Tehran. Journal of Organizational Learning and Leadership, 11(1), 1-18.

Saunila, M., Pekkola, S. \& Ukko, J. (2014). The relationship between innovation capability and performance: The moderating effect of measurement. International Journal of Productivity and Performance Management, 63(2), 234-249

Santos-Vijande, M. L. \& Álvarez-González, L. I. (2007). Innovativeness and organizational innovation in total quality oriented firms: The moderating role of market turbulence. Technovation, 27(9), 514-532

Sekaran, U. \& Bougie, R. (2016).Research Methods for Business: A Skill-Building Approach, $7^{\text {th }}$ Edition, John Wiley and Sons, Inc.

Shih, K. H., Wang, Y. H. \& Lin, W. R. (2014). A Multi-Criteria Decision Making for Innovation Services Attributes: An Empirical Study of Mobile Banking System. Journal of Testing and Evaluation, 43(4), 938-947.

Silva, 0. (2007) The Jack-of-All-Trades entrepreneur: Innate talent or acquired skill? Economics Letters, 97(2), 118-123.

Sinkula, J. M., Baker, W. E. \& Noordeweir, T. (1997). A framework for market-based organizational learning: Linking values, knowledge, and behavior. Journal of the Academy of Marketing Science, 25, 305-318.

Sivadas, E. \& Dwyer, F. R. (2000).An examination of organizational factors influencing new product success in internal and alliance-based processes. Journal of Marketing, 64(1), 31-49.

Slappendel, C. (1996). Perspectives on innovation in organizations. Organization Studies, 17(1), 107-129.

Slater, S. F. \& Nervier, J. C. (1995). Market oriented isn't enough: Build a learning organization. ReportMarketing Science Institute Cambridge Massachusetts, 35-36.

Sneyd, K. P. \& Rowley, J. (2004).Linking strategic objectives and operational performance: An action researchbased exploration. Measuring Business Excellence, 8(3), 42-51.

Sternberg, R. J., Kaufman, J. C. \& Pretz, J. E. (2004).A propulsion model of creative leadership. Creativity and Innovation Management, 13(3), 145-153.

Storey, C., Cankurtaran, P., Papastathopoulou, P. \& Hultink, E. J. (2016). Success Factors for Service Innovation: A Meta-Analysis. Journal of Product Innovation Management, 3(1).

Tamer Cavusgil, S., Calantone, R. J. \& Zhao, Y. (2003). Tacit knowledge transfer and firm innovation capability. Journal of Business \& Industrial Marketing, 18(1), 6-21.

Tellis, G., Prabhu, J. \&Chandy, R. (2009). Radical innovation across nations: The preeminence of corporate culture. Journal of Marketing, 73(1), 3-23.

Tidd, J. (2001). Innovation management in context: environment, organization and performance. International Journal of Management Reviews, 3(3), 169-183.

Tran, Q. \& Tian, Y (2013). Organizational structure: Influencing factors and on a firm. American Journal of Industrial and Business Management, 3, 229-236. 
Vaccaro, I. G., Jansen, J. J., Van Den Bosch, F. A. \& Volberda, H. W. (2012). Management innovation and leadership: The moderating role of organizational size. Journal of Management Studies, 49(1), 28-51.

Valmohammadi, C. (2012). Investigating innovation management practices in Iranian organizations. Innovation, 14(2), 247-255

Venkatraman, N. \& Ramanujam, V. (1986). Measurement of business performance in strategy research: A comparison of approaches. Academy of Management Review, 11(4), 801-814.

Wan, D., Ong, C. H. \& Lee, F. (2005). Determinants of firm innovation in Singapore. Technovation, 25(3), 261268

Wang, C. H., Chen, K. Y. \& Chen, S. C. (2012). Total quality management, market orientation and hotel performance: The moderating effects of external environmental factors. International Journal of Hospitality Management, 31(1), 119-129.

Westwood, R. \& Low, D. R. (2003).The multicultural muse culture, creativity and innovation. International Journal of Cross Cultural Management, 3(2), 235-259.

Weerawardena, J., O'Cass, A. \& Julian, C. (2006). Does industry matter? Examining the role of industry structure and organizational learning in innovation and brand performance. Journal of Business Research, 59(1), 37-45.

Wilson, W. T. (2014). Beating the Middle-Income Trap in Southeast Asia. The Heritage Foundation, August, 27(1).

Wiklund, J. \& Shepherd, D. (2005). Entrepreneurial orientation and small business performance: A configurational approach. Journal of Business Venturing, 20(1), 71-91.

Witell, L., Snyder, H., Gustafsson, A., Fombelle, P. \& Kristensson, P. (2016). Defining service innovation: A review and synthesis. Journal of Business Research, 3(1).

Yadav, M., Prabhu, J. \& Chandy, R. (2007).Managing the future: CEO attention and innovation outcomes. Journal of Marketing, 71(4), 84-101.

Zheng, W., Yang, B. \& Mclean, G.N. (2010).linking organizational culture, strategy and organizational effectiveness: Mediating role of knowledge management. Journal of Business Research, 63(7), 763771. doi:10.1016/j.jbusres.2009.06.005. 